\title{
Heavy metal concentration in fish tissues inhabiting waters of "Buško Blato" reservoar (Bosnia and Herzegovina)
}

\author{
Elizabeta Has-Schön • Ivan Bogut • Gordana Kralik • \\ Stjepan Bogut • Janja Horvatić • Milan Čačić
}

Published online: 19 August 2008

(C) Springer Science + Business Media B.V. 2008

\section{Erratum to: Environ Monit Assess (2008) \\ 144:15-22 \\ DOI 10.1007/s10661-007-9627-0}

The original version of this article unfortunately contained a mistake. The first name of the last author is incorrect. It should have been "Milan" instead of "Ivan".

The online version of the original article can be found under doi:10.1007/s10661-007-9627-0.

E. Has-Schön $(\varangle) \cdot$ J. Horvatić

Department of Biology, J.J. Strossmayer University,

Trg Lj. Gaja 6, 31000 Osijek, Croatia

e-mail: elschon@yahoo.com

I. Bogut · G. Kralik

Department of Animal Husbandry, Faculty of Agriculture, J.J. Strossmayer University,

Trg Sv. Trojstva 3, 31000 Osijek, Croatia

S. Bogut

Health Centre Grude,

Kraljice Katarine 8, Grude, Bosnia and Herzegovina

M. Čačić

Faculty of Food Technology, J.J. Strossmayer University,

F. Kuhača 18, 31000 Osijek, Croatia 